\title{
Report on ammonoid soft tissue remains revealed by computed tomography
}

\author{
R. Hoffmann ${ }^{1 *} \mathbb{D}$, D. Morón-Alfonso ${ }^{2,3}$, C. Klug ${ }^{4}$ and K. Tanabe ${ }^{5}$
}

\begin{abstract}
Findings of ammonoid soft tissues are extremely rare compared to the rich fossil record of ammonoid conchs ranging from the Late Devonian to the Cretaceous/Paleogene boundary. Here, we apply the computed-tomography approach to detect ammonoid soft tissue remains in well-preserved fossils from the Early Cretaceous (early Albian) of NE-Germany of Proleymeriella. The ammonites were found in glauconitic-phosphatic sandstone boulders. Analyses of the high-resolution Ct-data revealed the presence of cameral sheets, the siphuncular tube wall, and the siphuncle itself. The siphuncle is a long, segmented soft tissue that begins at the rear end of the body chamber and comprises blood vessels. Chemical analyses using energy-dispersive spectroscopy (EDS) showed that all preserved soft tissues were phosphatized and are now composed of fluorapatite. The same holds true for preserved shell remains that locally show the nacreous microstructure. We provide a short description of these soft tissue remains and briefly discuss the taphonomic pathway.
\end{abstract}

\section{Introduction}

In contrast to the soft parts of coleoid cephalopods (belemnites, squids, and octopuses) and in spite of the great abundance of ammonoid fossils, reports on ammonoid soft parts are very limited in number (see, e.g., Klug \& Lehmann, 2015; Klug et al., 2008, 2012, 2016, 2021; Polizzotto et al., 2015; Tanabe, Sasaki, et al., 2015). The scarcity of soft tissue preservation in ammonoids is often explained by the buoyancy apparatus, which prevents the carcasses from rapid burial. Even if remains of the soft tissue became mineralized, these may be hidden by the external shell and, therefore, difficult to recognize without partially destroying the specimen. Jaws, radulae, and parts of the oesophagus are the few body parts that are sclerotized, i.e., composed of a more resistant chitin-protein complex (Saunders et al., 1978; Hunt \& Nixon, 1981; Lowenstam et al., 1984; Gupta et al., 2008). The chitin makes these parts more resistant against decomposition

\section{Editorial Handling: Ji Cheng}

*Correspondence: rene.hoffmann@rub.de

${ }^{1}$ Institut Für Geologie, Mineralogie und Geophysik, Ruhr-Universität

Bochum, Universitätsstrasse 150, 44801 Bochum, Germany

Full list of author information is available at the end of the article when compared to non-sclerotized soft tissues. Accordingly, these are the most widely reported organic hard components of soft tissues (Closs, 1967a, 1967b; Hollingworth \& Hilton, 1999; Klug \& Jerjen, 2012; Klug \& Lehmann, 2015; Klug et al., 2012, 2016, 2021; Kruta et al. 2011, 2020; Landman et al., 2010; Lehmann, 1981; Lehmann \& Weitschat, 1973; Mapes et al., 2019; Tanabe, Kruta, et al., 2015; Wippich \& Lehmann, 2004). Besides, a few records exist for the presence of ammonoid gills (Klug et al., 2021; Lehmann, 1985; Lehmann \& Weitschat, 1973; Mironenko, 2015), and siphuncle (Mironenko, 2017 and references therein; Tanabe et al., 1982, 2000; Tanabe, Sasaki, et al., 2015). The siphuncle is a long, segmented soft tissue that begins at the rear soft body. The organic strand comprises blood vessels (two pairs of arteries and one vein in Nautilus), connecting tissue and epithelium (Barskov, 1990; Denton \& Gilpin-Brown, 1973; Greenwald et al., 1982; Hoffmann et al., 2015; Tanabe et al., 2000). In Nautilus and Spirula, the siphuncle is supported and partially surrounded by the calcareous septal necks, which are tubular extensions formed by septal material. The siphuncle of Nautilus and ammonites itself lies within the siphuncular tube wall, which is an organic hard tissue that is composed of conchiolin (Bandel \& 
Boletzky, 1979; Lowenstam et al., 1984; Obata et al., 1980). In ammonoids, the siphuncle starts within the initial chamber and passes through all chambers of the phragmocone and ends in the rear body chamber (Tanabe et al., 2005; Tanabe, Sasaki, et al., 2015).

Most of the rare reports of soft tissue preservation are limited to special depositional environments known from conservation Lagerstätten, such as, e.g., Bear Gulch (Carboniferous) Solnhofen-Eichstätt region (Late Jurassic) or Lebanon (Late Cretaceous; see Klug et al. (2021) for a more complete list). Recently, Klug et al. (2021) reported on a specimen from a Late Jurassic (Tithonian) locality in SW-Germany that was perhaps pulled out of its conch by a presumed coleoid predator, that for unknown reasons, dropped its prey, or it fell out of the conch. That unique finding and the special conservation conditions allowed for the preservation of the remnants of otherwise unknown soft tissues including, e.g., reproductive organs, gills, anus, digestive gland, crop, stomach, caecum, mantle, and the intestines.

Their finding demonstrates the importance of such conservation deposits for the reconstruction of extinct organisms. Similarly, new techniques can add to the understanding of former life forms. In case of extinct groups of organisms, such as ammonoids, the approach of computed and grinding tomography and their resulting physical and virtual models added a significant amount of palaeobiological information. For example, new information was gained about the functionality of their buoyancy apparatus, which corroborated that ammonoids could swim freely within the water column (Hoffmann et al., 2015; Lemanis, Korn, et al., 2016). Using similar approaches, ammonoid hydrostatics and hydrodynamics are now better understood (Hebdon et al., 2020; Peterman, Ciampaglio, et al., 2019b, Peterman, Hebdon, et al., 2020, Peterman, Hebdon, et al., 2020, Peterman, Yacobucci, et al., 2020). 3D data also improved our understanding of the function of septa (Lemanis et al., 2016b, 2020) and ultimately of their metabolism (Tajika et al., 2020). The computed tomography $(\mathrm{Ct})$ method could also be applied to detect soft tissue remains in well-preserved fossil material, e.g., cameral sheets, siphuncular membranes, the siphuncle itself, muscle attachment scars, or blood vessel imprints (Klug et al., 2008). For the detection of blood vessel imprints in Ct volume data, we provide an example for the modern Allonautilus scrobiculatus (Fig. 1).

Here, we describe for the first time, based on computed-tomography data, ammonoid soft tissue remains that were preserved within the conch of an Early Cretaceous (early Albian) Proleymeriella schrammeni from NE-Germany and briefly discuss the taphonomic history.

\section{Materials and methods}

The herein described specimens of Proleymeriella schrammeni (coll. No. RUB-Pal 11285, 11286) were collected by Werner Beckert from glacial erratic deposits in NE Germany (Wolgast-Hohendorf, Mecklenburg-Vorpommern). These deposits contain abundant Early Cretaceous (early Albian) glauconitic-phosphatic sandstone boulders (Fig. 2), which occasionally contain ammonites of the Leymeriella tardefurcata and earliest Douvilleiceras mammillatum Zones (see Lehmann et al., 2016 for details). The original aragonite shell material of the mostly hollow or partially sediment filled ammonites is diagenetically transferred into calcium phosphate. Some of the ammonites, however, still show iridescent shell parts (RUB-Pal 11287).

Both the actual specimen RUB-Pal 11285 and the computed-tomography data are stored at the Ruhr-Universität Bochum. Ct data were collected with $130 \mathrm{kV}$ voltage, $350 \mu \mathrm{A}$ current, and $500 \mathrm{~ms}$ exposure time resulting in a data set with the following dimensions $(X=1906$, $Y=2104, Z=1898$ slides) and a resolution of $9.75 \mu \mathrm{m}$ isotropic voxel size. The computed-tomographic data set (i.e., scalar volume) was transformed and reoriented with respect to the studied specimen using 3D grids employing the open-source program 3D Slicer (Fedorov et al., 2012). This allowed to obtain precise longitudinal and transversal cross sections of the specimen. A detailed description of this procedure will be presented in a separate work. Furthermore, an inverted grey filter was applied to facilitate visualization of the tomographic data sets, and chambers were labeled in order of their ontogenetic occurrence. Finally, 3D empirical models based on the structures described were obtained through a semiautomatic process, which consisted of a basic thresholding segmentation edited using the basic tools included in the 3D Slicer software. A second specimen (RUB-Pal 11286) was examined under the scanning electron microscope (SEM; Zeiss Gemini 2 - Merlin) with an acceleration voltage of $3 \mathrm{kV}$, a probe current of $36-54 \mathrm{pA}$, and a working distance of 14.9 to $6.8 \mathrm{~mm}$. Energy dispersive spectra were collected for the iridescent shell material (RUB-Pal 11287) and the siphuncle from specimen RUBPal 11286 with $20 \mathrm{kV}$ acceleration voltage and a working distance of $10 \mathrm{~mm}$ (Fig. 3d-e).

\section{Results}

\section{Geochemical composition}

Energy-dispersive analyses show that the primary aragonitic shell material was diagenetically transformed into fluorapatite with about $11 \%_{\text {mass }}$ of fluorine, 


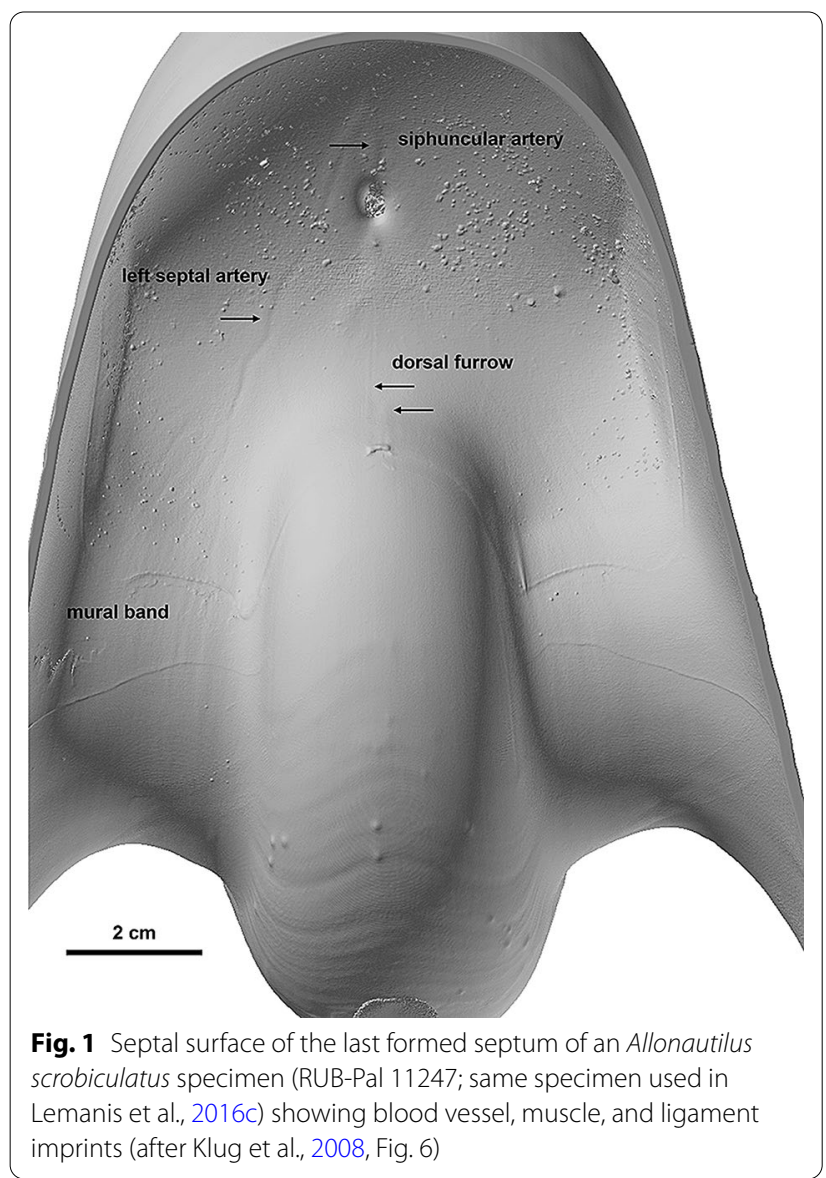

$15 \%_{\text {mass }}$ phosphorous, and a total of about $37 \%_{\text {mass }}$ calcium. The surrounding rock matrix is composed of a variety of grains including glauconite and quartz grains showing crusts also composed of fluorapatite with about $12 \%_{\text {mass }}$ of fluorine, $15 \%_{\text {mass }}$ phosphorous, and a total of $36 \%$ mass of calcium.

\section{Ct-volume data}

Inspection of the acquired high-resolution Ct-volume data and their subsequent reconstruction revealed first data of the specimen. The preserved conch has a maximum diameter of $14.27 \mathrm{~mm}$, with a whorl width of $5.92 \mathrm{~mm}$ and a whorl height of $5.69 \mathrm{~mm}$.

Consequently, at the largest preserved diameter, the conch is discoidal to subevolute in shape. The exceptional preservation allows the recognition of suture lines and the surface morphology of the virtual internal mould (Fig. 4a), septal morphology (Fig. 4b), and the number of chambers (hollow/filled) including the initial chamber (ic), ammonitella, and the position of the siphuncle (Fig. 4c).

\section{Siphuncle}

Only the last three (55-57) of 57 preserved chambers were filled with sediment, while most chambers are empty (Fig. 4c). The external shell wall shows no signs of shell breakages or deformation. The connecting ring/ siphuncular tube wall (stw), that connects successive chambers of the phragmocone, is preserved in the first 35 chambers, only interrupted in chambers 8 and 9, and reappearing in chambers $37-39$ as a collapsed structure, 47-49, and in chamber 51 (Fig. 4c). Closer inspection of the inner structures revealed the presence of a tubular structure (ts) within the siphuncular tube wall (Fig. 4c). The tubular structure has a diameter of about $0.11 \mathrm{~mm}$ and spans an area of about $0.007 \mathrm{~mm}^{2}$, which is around $8.87 \%$ of the stw area (Fig. 5). The tubular structure is visible in chambers $1-7,21-31$, and isolated as short segments on chambers 34, 35, 48, and 51 (Fig. 5). The lumen of ts is recognizable in just a few sections of these chambers, while it is collapsed lying on the siphuncle's ventral side or is strongly deformed otherwise (e.g., Fig. 4c, chambers 23-27; Figs. 5d, 7a).

From another specimen (RUB-Pal 11286), a part of the siphuncle was extracted and examined under the SEM (Fig. 6). That specimen displays small knobs on the surfaces of the stw and the ts. The siphuncular tube wall consists of a three-layered spherulitic structure on the external and internal surface. A similar three-layered structure is present in the tubular structure with a larger, subcentral, and three smaller, marginal openings (Fig. 6b). At the opposite end of the siphuncle fragment, the structure shows only two relatively large openings compared to the other end (Fig. 6c).

\section{Cameral sheets}

Based on orthoslice views of the specimen RUB-Pal 11285, membrane-like structures were identified as transversal cameral sheets (cs), due to the lack of a connection to the siphuncle and the relative position within the chambers, at the dorsal side of chambers 53 and 54 (see Polizzotto et al. 2015; Weitschat and Bandel, 1991; Fig. 7). After image post-processing and segmentation work, cameral sheets were found to be attached to the septa also in chambers 29, 30, and 43. These structures show signs of elasticity and slight deformation comparable to the tubular structure. Moreover, the cameral sheets share comparably high X-ray absorption properties when compared to the ts in Ct-images, which suggests that both the ts and cs share a similar composition. These cameral sheets could not be reconstructed completely due to their low thickness and the insufficient resolution. 


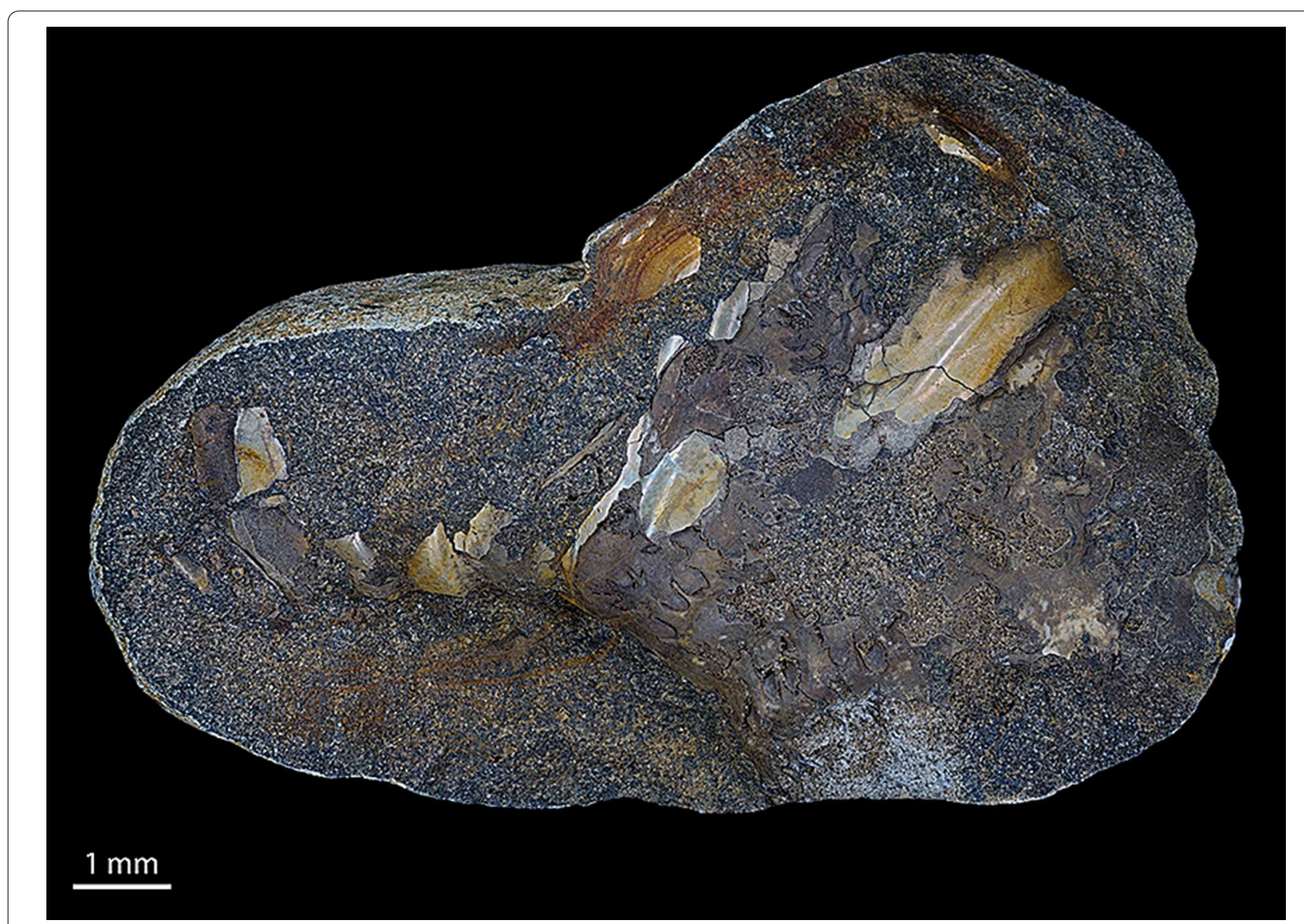

Fig. 2 Internal mould of an undetermined ammonite (RUB-Pal 11287) with visible suture line and partial shell remains that still show the typical iridescent behaviour of the original aragonitic shell, but is now fluorapatite

The thickest membrane was found in chamber 53 and is $0.03 \mathrm{~mm}$ thick (Fig. 7).

\section{Ammonitella}

Several structures of the ammonitella (embryonic shell) were visualized using the tomographic data (Fig. 8). These structures are labeled according to De Baets et al. (2015) and include the initial chamber (ic=protoconch), the subprismatic initial chamber wall (sp-icw), the prismatic ventral wall ( $\mathrm{p}-\mathrm{vw})$, the primary constriction $(\mathrm{pc})$, the primary varix (pv), and possibly the caecum (ca). The proseptum and the prosiphon were not recognized. The tubular structure is preserved already within the ammonitella, but may also represent the siphuncular tube wall. The ammonitella is about $1.16 \mathrm{~mm}$ in diameter with a whorl width of $0.72 \mathrm{~mm}$ and an umbilical width of $0.16 \mathrm{~mm}$ at its largest diameter. These morphological parameters translate into a pachyconic to involute embryonic conch (see Klug et al. 2015). The initial chamber is spindle-like to sub-spherical in shape and has a maximum and minimum diameter of 0.64 and $0.47 \mathrm{~mm}$, respectively, and reaches $0.60 \mathrm{~mm}$ in width (see De Baets et al., 2015).

\section{Discussion}

The fossil record of soft tissue remains is restricted to localities and strata with exceptional preservational conditions. EDS spectra revealed the presence of large amounts of phosphate and fluorine in the shell (Fig. 3d, e, see Tanabe et al., 2000 and Mironenko, 2017 for similar EDS spectra). Furthermore, the siphuncular remains also contain high amounts of phosphate, thus suggesting the taphonomic process of phosphatization as responsible agent for the exceptional preservation of the herein described early Albian ammonites. The process of soft tissue phosphatization increased during the Cretaceous to Eocene compared to the Palaeozoic (Dornbos, 2011). Phosphatization, however, still is a rare mode of fossil 

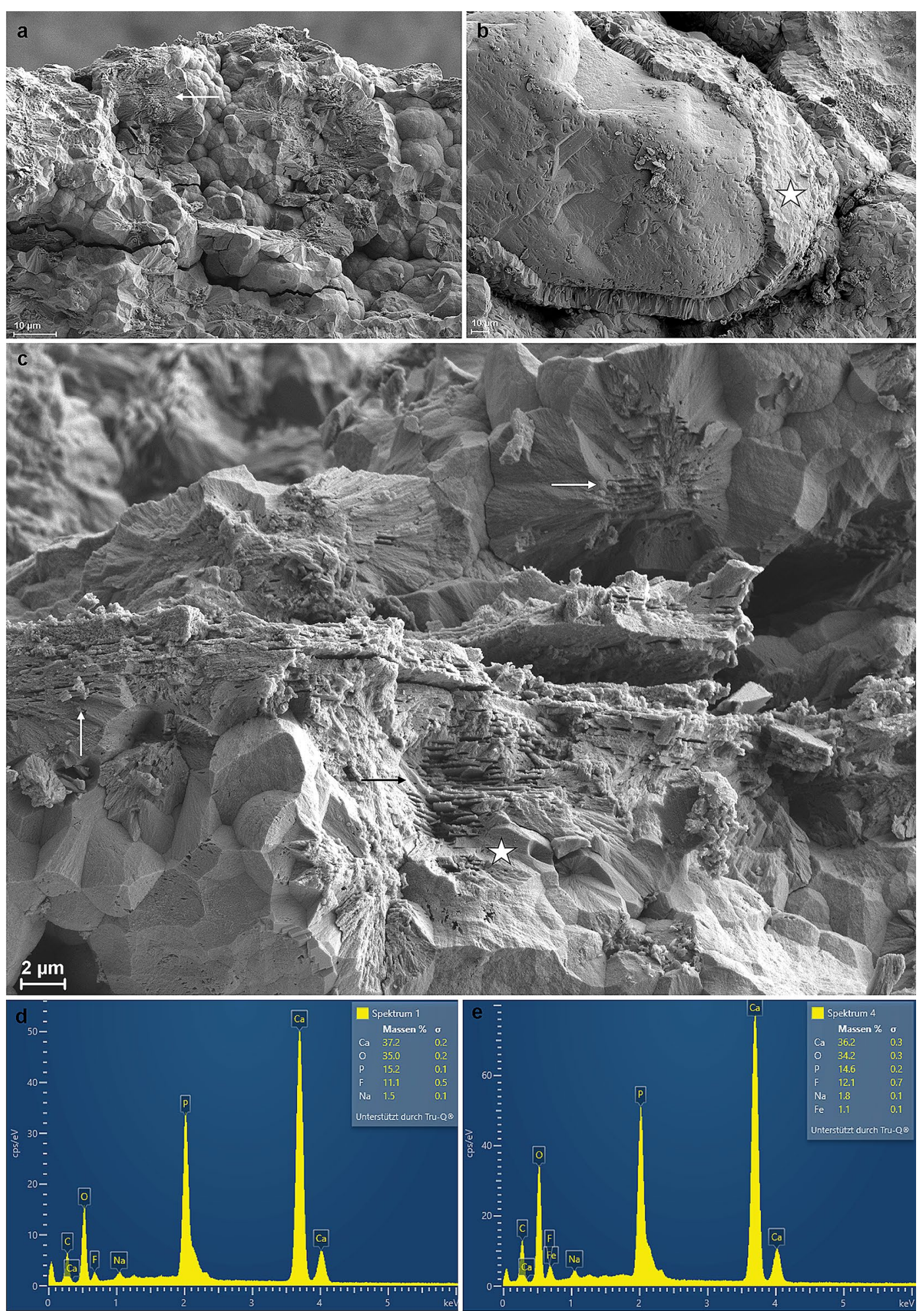

Fig. 3 Geochemical composition of the originally aragonitic shell and the surrounding rock material from specimen RUB-Pal 11287, a, c both show relics of the original tablet microstructure (arrows), b shows a quartz grain coated with a fluorapatite crust, $\mathbf{d}$ EDS spectrum from the phosphate collected in the area show in C (star), e EDS spectrum collected from the crust shown in B (star) 

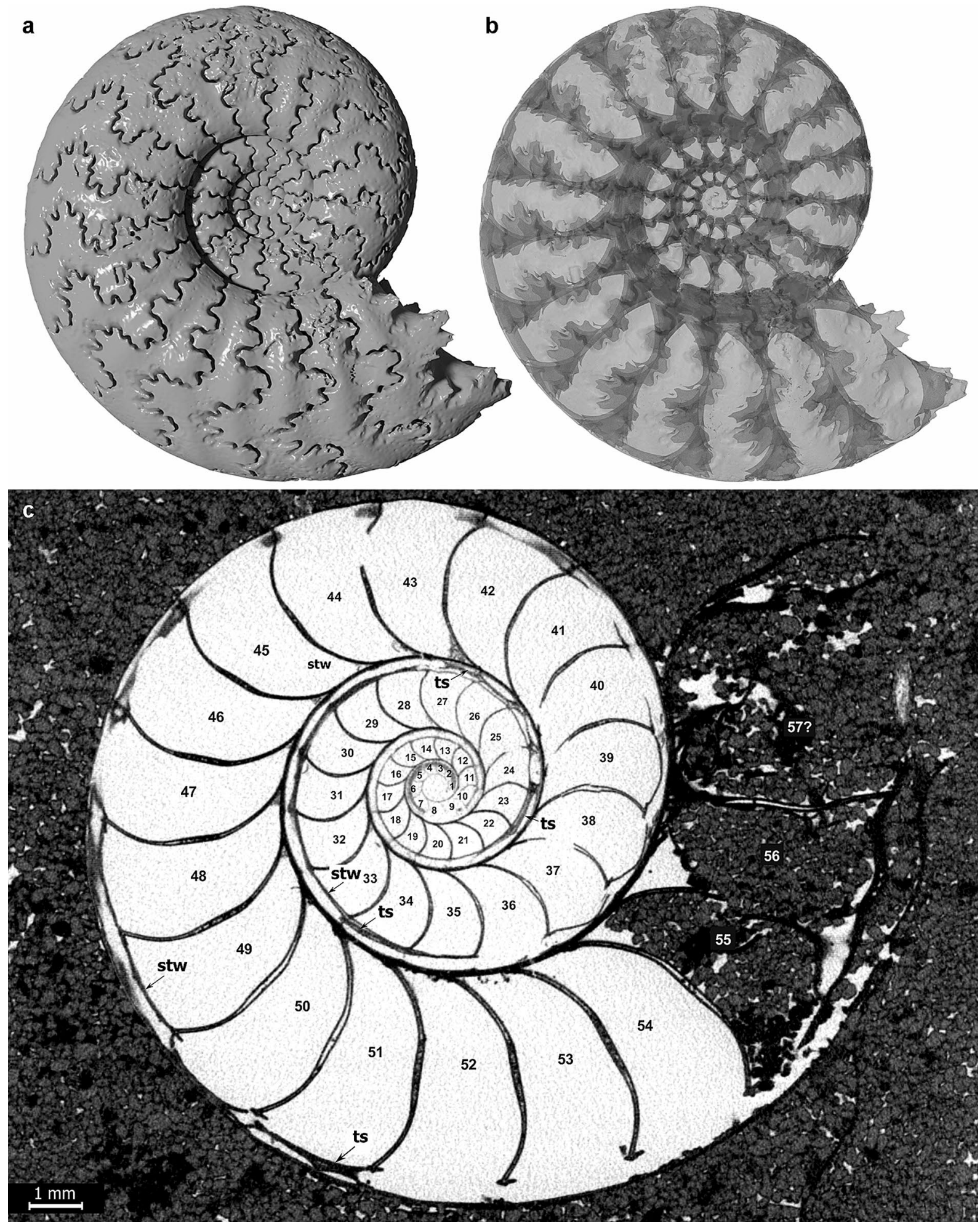

Fig. 4 Proleymeriella schrammeni, NE-Germany, early Albian, RUB-Pal 11285 a 3D empirical model in lateral view showing the suture lines and morphology of the internal mould for all hollow chambers, $\mathbf{b}$ same model and orientation in a semi-transparent appearance showing the shape of the septa and septal spacing for all hollow chambers, c Virtual longitudinal cross section showing 57 preserved chambers (not filled/filled) including the initial chamber (ic - see Fig. 8 for a close up), and the ventral position of the siphuncle. The chambers were labeled following the occurrence during ontogeny, ts tubular structure, stw siphuncular tube wall, note: grey scale values inverted 


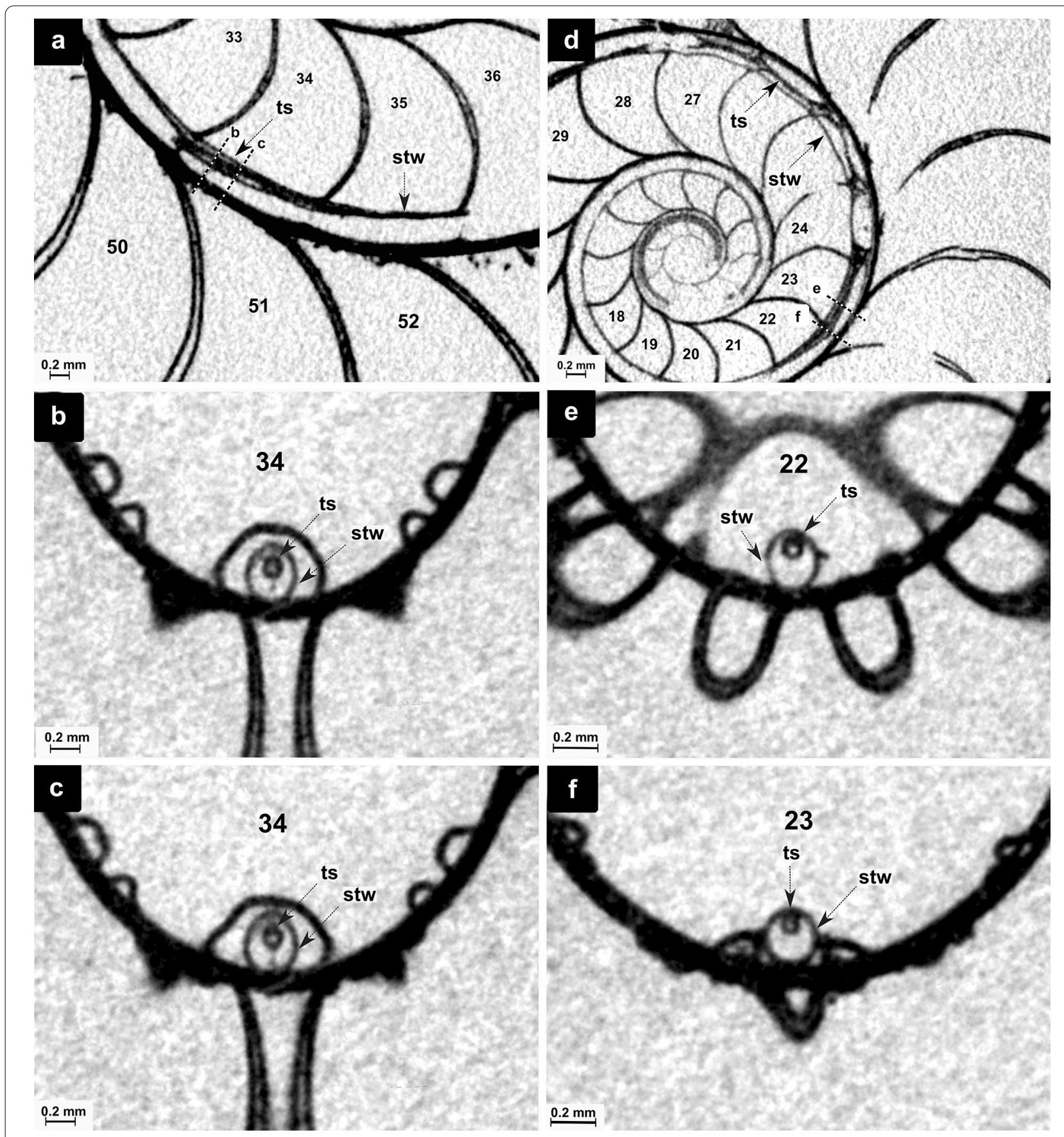

Fig. 5 Proleymeriella schrammeni, NE-Germany, early Albian, RUB-Pal 11285, six orthoslices showing sections of the specimen and potential soft tissue remains. a longitudinal cross section showing the tubular structure (ts) inside the siphuncular tube wall (stw) within chamber 34, stippled lines show cutting plane for Fig. $\mathbf{b}, \mathbf{c} ; \mathbf{b}, \mathbf{c}$ cross sections of the structures indicated in A showing the siphuncular tube wall and the tubular structure sitting within the stw; $\mathbf{d}$ longitudinal cross sections showing the tubular structure (ts) inside the siphuncular tube wall (stw) within chamber 22-23, stippled lines show the cutting planes for $\mathbf{e}, \mathbf{f} ; \mathbf{e}, \mathbf{f}$ cross sections of the structures indicated in $\mathbf{d}$, showing the siphuncular tube wall and the tubular structure sitting within the stw, note: grey scale values inverted 
preservation that allows the preservation of hard and soft tissues on a cellular and even subcellular level (e.g., Hagadorn et al., 2006). It is noteworthy to point out that phosphatization is a highly selective and biased taphonomic pathway (Dornbos, 2011).

Lehmann et al. (2016) discussed the general depositional environment for the concretions that bear the largely hollow-preserved phosphatized ammonites described herein. They argued that sandstone concretions rich in glauconite with phosphate cements indicate a marine environment with an organic rich sedimentation and low sedimentation rates (Tucker, 1985). Such conditions can be found at the outer shelf or in upwelling areas (Lehmann et al., 2016). The relatively large quartz grains, however, indicate a deposition under higher water energies, i.e., relatively shallow marine and potentially close to the coastline. Recent phosphorites typically form in environments characterized by low sedimentation rates, strong seafloor currents, and a large influx of organic matter due to high primary productivity (Baturin, 1999; Föllmi, 1996). Phosphatized sandstones have a higher resistance against mechanical erosion due to reworking, and accordingly can be found in higher concentrations in reworked horizons which is the case for our examples of glacial erratic boulders (Jarvis, 2006; Tucker, 1985). That explains their high abundance within some specific sand layers in NE-Germany and elsewhere. Specifically, for the concretions examined herein, Fechner and Schneider (1997) found that phosphatization took place in two phases.

The iridescent shell fragments (Fig. 2) and the here described soft tissue remains (Fig. 5-7) are two prime examples underlining the importance of phosphatized fossils. The iridescent shell (hard or mineralized tissue) demonstrates the preservation of submicrometer-scale structures, namely, the columnar nacre of the ammonite shell. The originally aragonitic ammonoid shell (Bøggild, 1930; Immenhauser et al., 2016; Keupp, 2000) is composed of an outer and inner prismatic layer and a middle layer composed of thin (submicrometer) aragonitic tablets forming the columnar nacre structure. Aragonite, however, is metastable under atmospheric conditions and easily transforms into blocky calcite losing all its microstructural information (Dullo \& Bandel, 1988).

By contrast, preserved soft tissue remains, such as the siphuncular tube wall, the siphuncle, and cameral sheets, show the potential of phosphatization to preserve delicate non-mineralized tissues and their anatomy (Figs. 67). Because the original soft tissue is not preserved, such structures are preferable called pseudomorphs: they are generally formed by the replacement of tissues by, e.g., phosphates, carbonates, or pyrite (see Mähler et al., 2020 for more details). The preservation of these organic structures suggests an early diagenetic phosphatization (Weitschat, 1986; Weitschat and Bandel, 1991). Hewitt and Westermann (1983) and Lehmann et al., (2016) reported that the siphuncular tube wall is preserved as francolite, which is a carbonate-rich variant of fluorapatite. Most likely, the process of phosphatization takes place early during diagenesis (Allison, 1988; Briggs et al. 1993; Hewitt \& Westermann, 1983; Tanabe, Sasaki, et al., 2015; Wilby et al. 2004). Partially deformed and collapsed soft tissue structures suggest that their phosphatization took place during bacterial and fungal activity (Allison, 1988; Maeda \& Seilacher, 1996; Tanabe, Sasaki, et al., 2015). Potentially, the phosphate required for phosphatization stems largely from their own decaying soft tissues due to, e.g., microbial breakdown of organic compounds, such as adenosine triphosphate (Briggs \& Kear, 1993, Prévot and Lucas 1984, Wilby et al. 2004). Under oxic conditions, chemical components of organic matter will combine to ferric hydroxides quickly. Accordingly, anoxic conditions are required for the formation of phosphatized soft tissues (Allison, 1988). Phosphatization of soft tissues may have taken place within days to weeks (Föllmi, 1996). The bacterial decay of soft tissue produced not only enough phosphate, but also lowered the $\mathrm{pH}$ sufficiently to phosphatize the remaining non-decayed tissues (Klug et al., 2005). Lowering of the $\mathrm{pH}(<6.38=$ the phosphatization window that favors the precipitation of apatite) suggests a "closed system" that keeps the acidic biproducts of microbial metabolism, such as $\mathrm{CO}_{2}$ and $\mathrm{H}_{2} \mathrm{SO}_{4}$ (Briggs \& Kear, 1993; Briggs \& Wilby, 1996, Clements et al. 2017). Here, we argue that the phragmocone itself served as a "closed system" comparable to the cuticular envelope of crustaceans (Briggs \& Wilby, 1996; Mähler et al., 2020). Within the phragmocone chambers, the ion concentrations and low $\mathrm{pH}$ levels generated by microbial decomposition were maintained, while the body chamber (that contained the largest part of the soft tissues) represents an "open system" allowing the complete degradation of soft tissues without

(See figure on next page.)

Fig. 6 Proleymeriella schrammeni, NE-Germany, early Albian, RUB-Pal 11286, a overview of the siphuncle segment with the surface of the siphuncular tube wall and parts of the septum attached, $\mathbf{b}$ apertural end of the siphuncle with one main opening (?vein) and a smaller opening (?artery) which may correspond with the smaller opening in $\mathbf{c}$, the other two openings are unclear and could represent two arteries or diagenetic artifacts, c adapertural end with one larger (?vein) and one smaller openings (?artery), $v$ vein, $a$ artery, ts tubular structure, stw siphuncular tube wall 


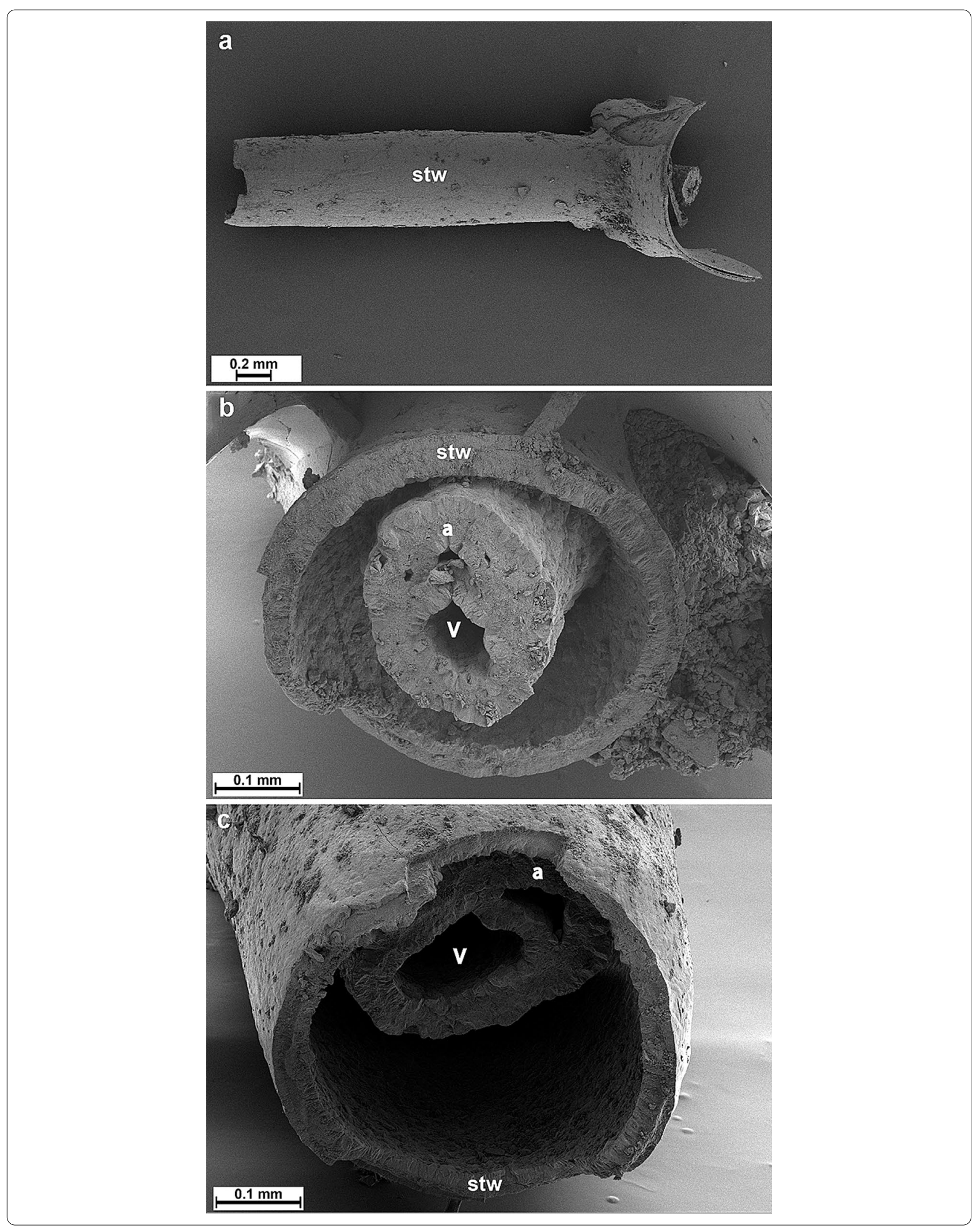




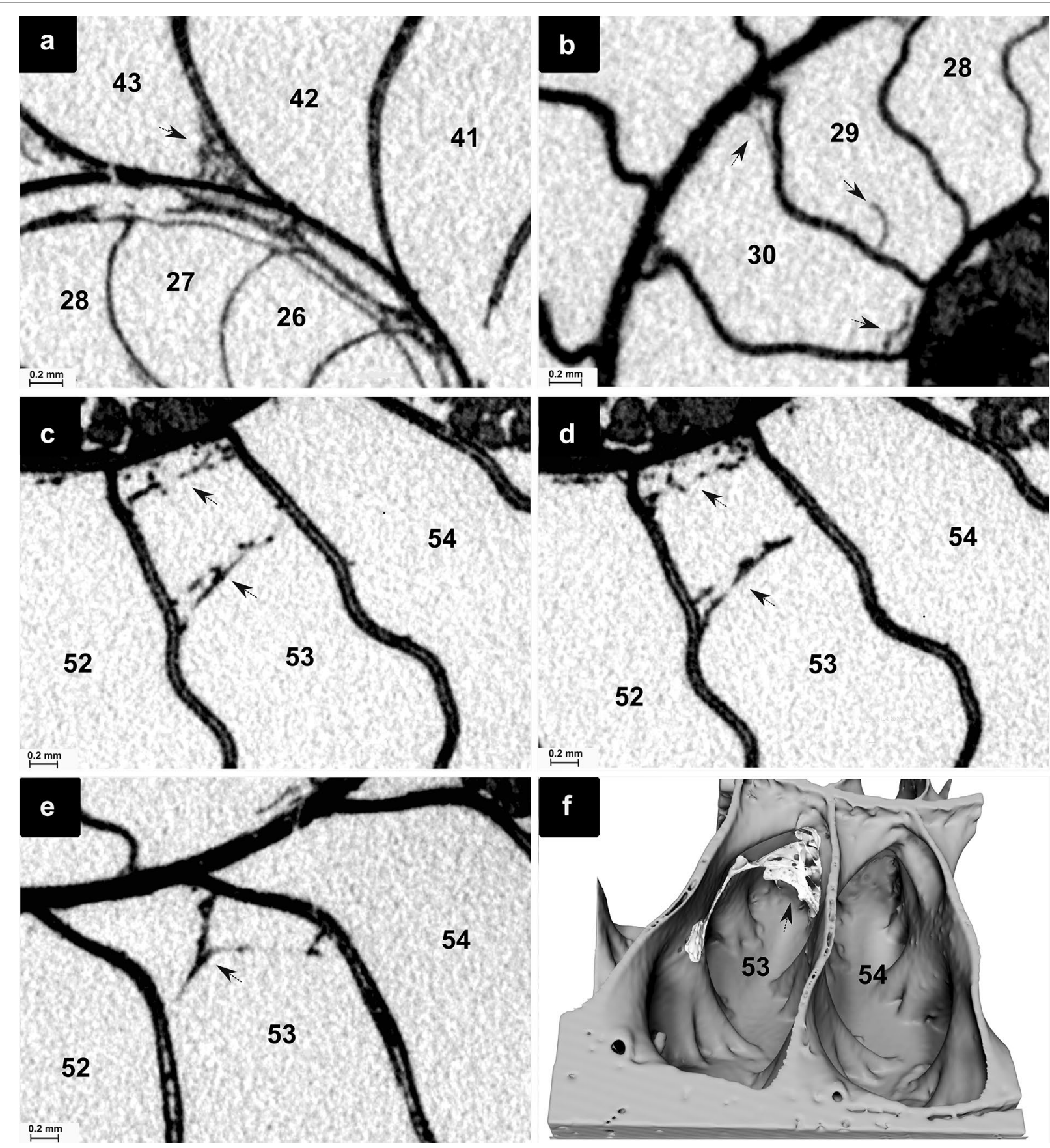

Fig. 7 Proleymeriella schrammeni, NE-Germany, early Albian, RUB-Pal 11285, a-e longitudinal orthoslices arrows indicate dorsal position of cameral sheets inside the chambers 29,30,43, and 53. c-e show the continuity of the cameral sheets thorough the chamber. $\mathbf{f} 3 \mathrm{D}$-empirical model obtained from the tomographic dataset showing the dorsal position of the cameral sheets (white =cameral sheets, grey= conch), note: grey scale values inverted 


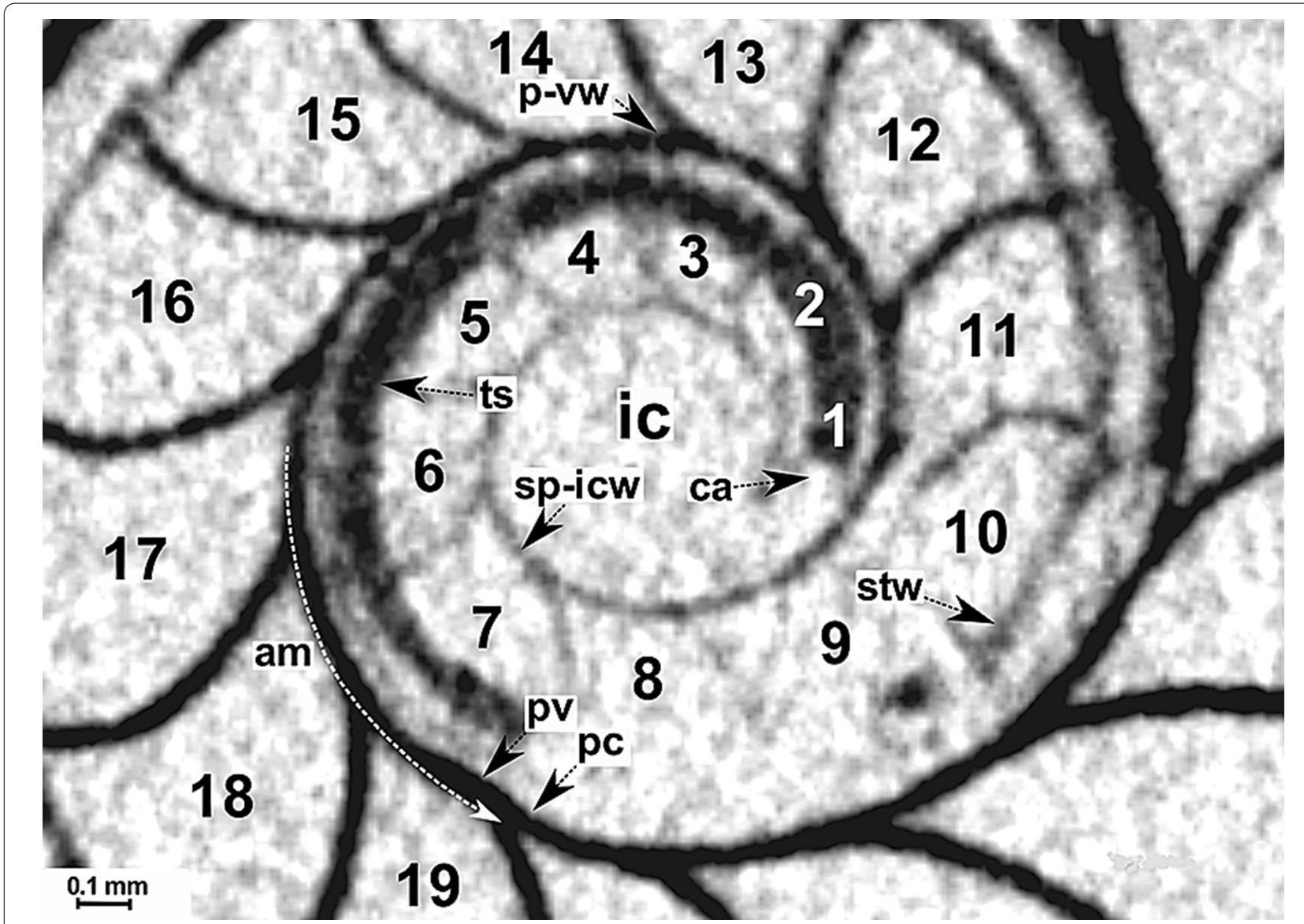

Fig. 8 Proleymeriella schrammeni, NE-Germany, early Albian, RUB-Pal 11285, longitudinal section of the specimen showing the inner structures of the ammonitella. Am ammonitella, ca caecum, ic initial chamber, sp-icw subprismatic initial chamber wall, $p$ - $v w$ prismatic ventral wall of ammonitella, $p c$ primary constriction, $p v$ primary varix; ts tubular structure (most likely the siphuncle), stw = siphuncular tube wall, note: grey scale values inverted

entering the phosphatization window. Phosphatization in a closed system may also explain the preservation of phosphatized pellicle and siphuncle as shown by Weitschat (1986) and herein (Fig. 9a, b) for the Middle Triassic ammonite Amphipopanoceras. After phosphatization took place the phragmocone chambers got filled will calcite which is also observed for other localities, e.g., Lower Cretaceous (Albian) of Madagascar (Fig. 9c, d, ammonite: Desmoceras sp.). Here, the presence of small framboid pyrite indicates the anoxic conditions during siphuncular phosphatization.

The siphuncular tube wall of Proleymeriella partially contains remnants of the siphuncle and is also preserved within the ammonitella. The siphuncle extracted from a second specimen from the same locality shows one large opening at both ends, which most likely represents the siphuncular vein. It is uncertain whether the other observed openings represent the siphuncular arteries or not.

The phosphatized membrane-like structures occur in the dorsal parts of a number of chambers showing no connection to the siphuncle. Accordingly, we regard these cameral sheets as transversal cameral sheets (Polizzotto et al., 2015). Unfortunately, our data on transversal cameral sheets do not provide insights about their formation (secretion model versus desiccation model: see Weitschat and Bandel 1991, Landman et al., 2006, Polizzotto et al., 2015 for details). 

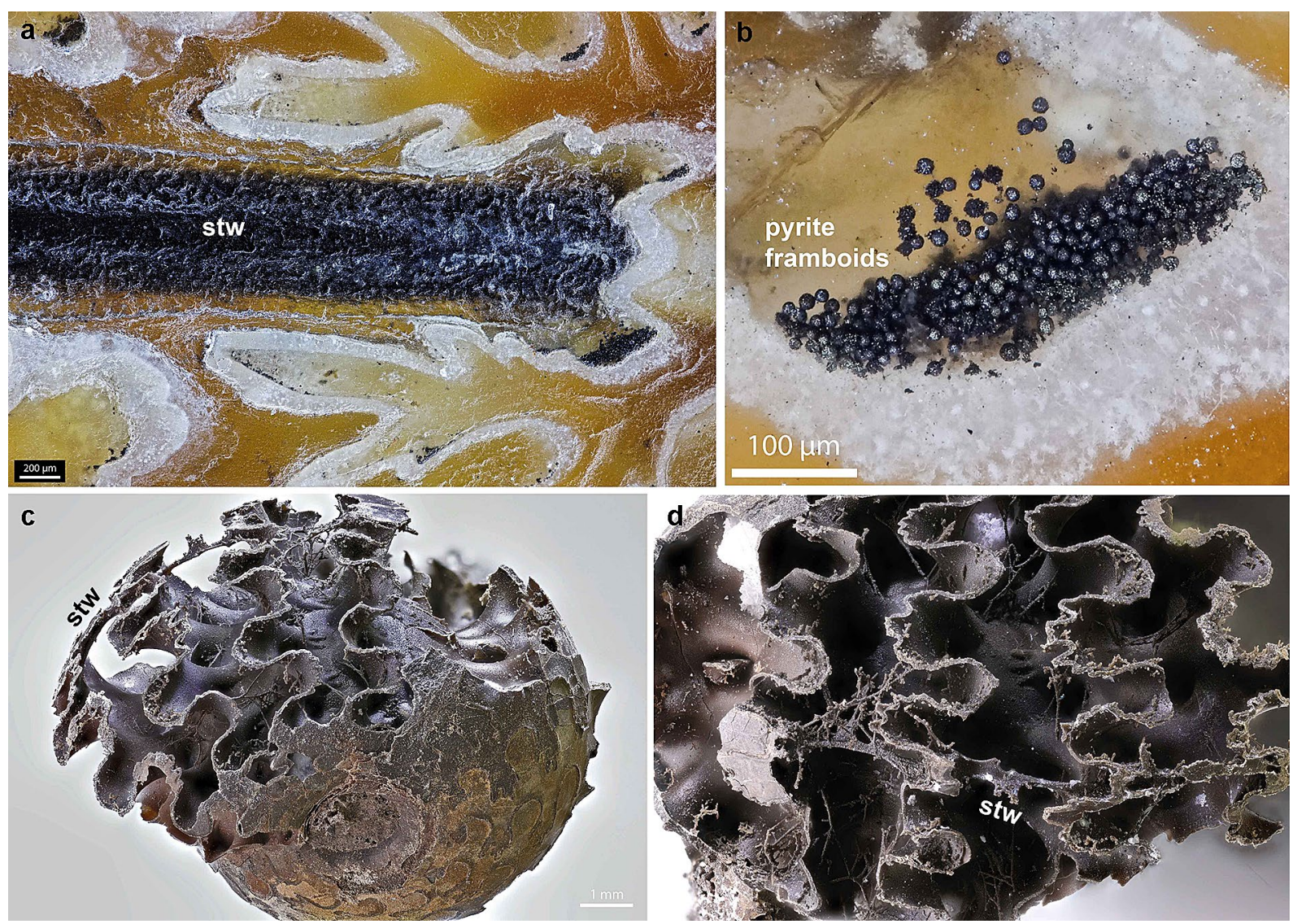

Fig. 9 Additional examples of phosphatized organic remains of ammonoids. a, b Desmoceras sp. (RUB-Pal 11288), Lower Cretaceous (Albian) of Madagascar with the phosphatized siphuncular tube wall preserved. Presence of pyrite framboids indicate anoxic conditions during early diagenesis. c, d Amphipopanoceras sp. (RUB-Pal 11289), Middle Triassic, Spitsbergen (Greenland) with phosphatized pellicle, siphuncular tube wall remains and algae or fungi

\section{Conclusion}

Based on high-resolution Ct-data, we described that the presence of soft tissue remains for early Albian Proleymeriella including transversal cameral sheets, the siphuncular tube wall, and the siphuncular soft tissues. Potentially, the siphuncular vein is visible, while the presence or absence of the arteries has not been clearly confirmed in the present material. Preservation of soft tissue remains as pseudomorphs of fluorapatite due to phosphatization that took place under "closed system" conditions is discussed. Conditions are comparable with microenvironments found in decomposing crustacean carcasses and also affected the primary aragonitic shell which is now transformed to fluorapatite or francolitea carbonate rich fluorapatite. The examination of further specimens with a similar preservation will help clarifying the homologisation of the siphuncular organs.

\section{Abbreviations}

am: Ammonitella; ca: Caecum; cs: Cameral sheets; ic: Initial chamber; sp-icw: Subprismatic initial chamber wall; $p$-vw: Prismatic ventral wall of ammonitella; pc: Primary constriction; pv: Primary varix; stw: Siphuncular tube wall; ts: Tubular structure.

\section{Acknowledgements}

$\mathrm{RH}$ acknowledges Werner Beckert and the late Wolfgang Weitschat for putting specimens to our disposal and Dieter Buhl for providing images shown in Fig. 9.

\section{Authors' contributions}

$\mathrm{RH}$ had the project idea and wrote most part of the text with contributions of all co-authors. DMA did the CT-data analysis and imaging, $\mathrm{RH}$ and DMA analyzed and interpreted the results. All authors read and approved the final manuscript and revised the figures.

\section{Funding}

Open Access funding enabled and organized by Projekt DEAL.

\section{Availability of data and materials}

The generated and analyzed data and specimens used for this study are shown in the manuscript and stored at the Ruhr-Universität Bochum. 


\section{Declarations}

\section{Competing Interests}

The authors declare that they have no competing interests.

\section{Author details}

${ }^{1}$ Institut Für Geologie, Mineralogie und Geophysik, Ruhr-Universität Bochum, Universitätsstrasse 150, 44801 Bochum, Germany. ${ }^{2}$ Facultad de Ciencias Exactas Y Naturales, Departamento de Ciencias Geológicas, Universidad de Buenos Aires, Área de Paleontología, Ciudad Universitaria, Pab. 2, C1428EGA Buenos Aires, Argentina. ${ }^{3}$ CONICET-Universidad de Buenos Aires, Instituto de Estudios Andinos "Don Pablo Groeber" (IDEAN), Buenos Aires, Argentina. ${ }^{4}$ Paläontologisches Institut und Museum, Universität Zürich, Karl Schmid-Strasse 4, CH-8006 Zürich, Switzerland. ${ }^{5}$ The University Museum, The University of Tokyo, 7-3-1 Hongo, Bunkyo Ward, Tokyo 113-0033, Japan.

\section{Received: 26 January 2021 Accepted: 12 April 2021}

\section{Published online: 02 June 2021}

\section{Open Access}

This article is licensed under a Creative Commons Attribution 4.0 International License, which permits use, sharing, adaptation, distribution and reproduction in any medium or format, as long as you give appropriate credit to the origina author(s) and the source, provide a link to the Creative Commons licence, and indicate if changes were made. The images or other third party material in this article are included in the article's Creative Commons licence, unless indicated otherwise in a credit line to the material. If material is not included in the article's Creative Commons licence and your intended use is not permitted by statutory regulation or exceeds the permitted use, you will need to obtain permission directly from the copyright holder. To view a copy of this licence, visit http://creativecommons.org/licenses/by/4.0/

\section{References}

Allison, P. A. (1988). Phosphatized soft-bodied squids from the Jurassic Oxford Clay. Lethaia, 21, 403-410. https://doi.org/10.1111/j.1502-3931.1988.tb017 69.x

Baets, K. D., Landman, N. H., \&Tanabe, K. (2015). Ammonoid embryonic development. In C. Klug, D. Korn, K. De Baets, I. Kruta, \& R. H. Mapes (Eds.), Ammonoid paleobiology: From anatomy to ecology. (pp. 113-205). Springer. https://doi.org/10.1007/978-94-017-9630-9_5

Bandel, K., \&Von Boletzky, S. (1979). A comparative study of the structure, development and morphological relationships of chambered cephalopod shells. Veliger, 21, 313-354

Barskov, I. S. (1990). Internal structure of siphuncle of the Late Jurassic ammonite Virgatites virgatus. Trans Paleont Inst, 243, 127-132

Baturin, G. N. (1999). Hypothesis of phosphogenesis and ocean environment. Lithology and Mineral Resources. Litol Polezn Iskop, 34, 451-472

Bøggild OB (1930) The Shell structure of the mollusks. D. Kgl. Danske Vidensk. Selsk. Skrifter, Naturvidensk. Og Mathem. Afd., 9 Raekke II. 2:233-326

Briggs, D. E. G., \& Kear, A. J. (1993). Fossilization of soft tissue in the Laboratory. Science, 259, 1439-1442. https://doi.org/10.1126/science.259.5100.1439

Briggs, D. E. G., Kear, A. J., Martill, D. M., \& Wilby, P. R. (1993). Phosphatization of soft-tissue in experiments and fossils. Journal of the Geological Society, 150, 1035-1038

Briggs, D. E. G., \& Wilby, P. R. (1996). The role of the calcium carbonate-calcium phosphate switch in the mineralization of soft-bodied fossils. Journal of the Geological Society, 153, 665-668. https://doi.org/10.1144/gsjgs.153.5. 0665

Clements, T., Colleary, C., De Baets, K., \& Vinther, J. (2017). Buoyancy mechanisms limit preservation of coleoid cephalopod soft tissues in Mesozoic Lagerstätten. Palaeontology, 60, 1-14. https://doi.org/10.1111/pala.12267

Closs, D. (1967a). Goniatiten mit Radula und Kieferapparat in der Itararé-Formation von Uruguay. Paläontologische Zeitschrift, 41, 19-37. https://doi. org/10.1007/BF02998546

Closs, D. (1967b). Upper Carboniferous anaptychi from Uruguay. Ameghiniana, $5,145-148$

Denton, E. J., \& Gilpin-Brown, J. B. (1973). Floatation mechanisms in modern and fossil cephalopods. In F. S. Russell \& M. Yonge (Eds.), Advances in marine biology. (Vol. 11, pp. 197-268). Academic Press. https://doi.org/10. 1016/S0065-2881(08)60270-9

Dornbos, S. Q. (2011). Phosphatization through the phanerozoic. In P. A. Allison \& D. J. Bottjer (Eds.), Taphonomy: Process and bias through time. (pp. 435-456). Springer Netherlands. https://doi.org/10.1007/978-90-4818643-3_12

Dullo, W. C., \& Bandel, K. (1988). Diagenesis of molluscan shells: A case study from cephalopods. In J. Wiedmann \& J. Kullmann (Eds.), Cephalopodspresent and past. (pp. 719-729). Schweizerbart (Stuttgart).

Fechner GG, Schneider S (1997) Untersuchungen an einem unterkretazischen Phosphorit-Geschiebe aus Zarrenthin [Examination of a Lower Cretaceous phosphatic glacial drift from Zarrenthin (Vorpommern, Germany)]Berliner Beiträge zur Geschiebeforschung. 1997:91-100

Fedorov, A., Beichel, R., Kalpathy-Cramer, J., Finet, J., Fillion-Robin, J.-C., Pujol, S., Bauer, C., Jennings, D., Fennessy, F., Sonka, M., Buatti, J., Aylward, S., Miller, J. V., Pieper, S., \& Kikinis, R. (2012). 3D Slicer as an image computing platform for the Quantitative Imaging Network. Magnetic resonance imaging, 30, 1323-1341. https://doi.org/10.1016/j.mri.2012.05.001

Föllmi, K. B. (1996). The phosphorus cycle, phosphogenesis and marine phosphate-rich deposits. Earth-Science Reviews, 40, 55-124. https://doi. org/10.1016/0012-8252(95)00049-6

Greenwald, L., Cook, C. B., \&Ward, P. D. (1982). The structure of the chambered Nautilus siphuncle: The siphuncular epithelium. Journal of Morphology, 172, 5-22. https://doi.org/10.1002/jmor.1051720103

Gupta, N. S., Briggs, D. E. G., Landman, N. H., Tanabe, K., \& Summons, R. E. (2008) Molecular structure of organic components in cephalopods: Evidence for oxidative cross linking in fossil marine invertebrates. Organic Geochemistry, 39, 1405-1414. https://doi.org/10.1016/j.orggeochem.2008.06.008

Hagadorn, J. W., Xiao, S., Donoghue, P. C. J., Bengtson, S., Gostling, N. J., Pawlowska, M., Raff, E. C., Raff, R. A., Turner, F. R., Chongyu, Y., Zhou, C., Yuan, X., McFeely, M. B., Stampanoni, M., \& Nealson, K. H. (2006). Cellular and subcellular structure of neoproterozoic animal embryos. Science, 314, 291-294. https://doi.org/10.1126/science.1133129

Hebdon, N., Ritterbush, K., \& Choi, Y. (2020). Computational fluid dynamics modeling of fossil ammonoid shells. Palaeontologia Electronica, 23(1), a21. https://doi.org/10.26879/956

Hewitt, R. A., \&Westermann, G. E. G. (1983). Mineralogy, structure and homology of ammonoid siphuncles. Neues Jahrbuch fürGeologie und Paläontologie, Abhandlungen, 165, 378-396

Hoffmann, R., Lemanis, R., Naglik, C., \& Klug, C. (2015). Ammonoid Buoyancy. In C. Klug, D. Korn, K. De Baets, I. Kruta, \& R. H. Mapes (Eds.), Ammonoid Paleobiology: From anatomy to ecology. (pp. 613-648). Netherlands, Dordrecht: Springer. https://doi.org/10.1007/978-94-017-9630-9_16

Hollingworth NT, Hilton J (1999) Fossil sheds new light on ammonites. New Scientist, 4th Sept 1999, 25

Hunt, S., \& Nixon, M. (1981). A comparative study of protein composition in the chitin-protein complexes of the beak, pen, sucker disc, radula and oesophageal cuticle of cephalopods. Comparative Biochemistry and Physiology Part B: Comparative Biochemistry, 68, 535-546. https://doi.org/ 10.1016/0305-0491(81)90071-7

Immenhauser, A., Schöne, B. R., Hoffmann, R., \& Niedermayr, A. (2016). Mollusc and brachiopod skeletal hard parts: Intricate archives of their marine environment. Sedimentology, 63, 1-59

Jarvis, I. (2006). The Santonian-Campanian phosphatic chalks of England and France. Proceedings of the Geologists' Association, 117(2), 219-237. https:// doi.org/10.1016/S0016-7878(06)80011-8

Keupp H (2000) Ammoniten paläobiologische Erfolgsspirlane. 165 pp., Thorbecke Verlag.

Klug, C., Frey, L., Korn, D., Jattiot, R., \& Rücklin, M. (2016). The oldest Gondwanan cephalopod mandibles (Hangenberg Black Shale, Late Devonian) and the mid-Palaeozoic rise of jaws. Palaeontology, 59, 611-629. https://doi.org/ 10.1111/pala.12248

Klug, C., Hagdorn, H., \& Montenari, M. (2005). Phosphatized soft-tissue in Triassic Bivalves. Palaeontology, 48, 833-852. https://doi.org/10.1111/j. 1475-4983.2005.00485.x

Klug, C., \& Jerjen, I. (2012). The buccal apparatus with radula of a ceratitic ammonoid from the German Middle Triassic. Geobios, 45, 57-65. https:// doi.org/10.1016/j.geobios.2011.12.001

Klug, C., Korn, D., Landman, N. H., Tanabe, K., De Baets, K., \& Naglik, C. (2015). Describing Ammonoid Conchs. In C. Klug, D. Korn, K. De Baets, I. 
Kruta, \& R. H. Mapes (Eds.), Ammonoid Paleobiology: From anatomy to ecology. (pp. 3-24). Springer Netherlands. https://doi.org/10.1007/ 978-94-017-9630-9_1

Klug C, Lehmann J (2015) soft part anatomy of ammonoids. In: Reconstructing the animal based on exceptionally preserved specimens and actualistic comparisons, vol. 43. Pp. 507-529. doi:https://doi.org/10.1007/978-94017-9630-9_12

Klug, C., Meyer, E. P., Richter, U., \& Korn, D. (2008). Soft-tissue imprints in fossil and Recent cephalopod septa and septum formation. Lethaia, 41, 477-492. https://doi.org/10.1111/j.1502-3931.2008.00100.x

Klug, C., Riegraf, W., \& Lehmann, J. (2012). Soft-part preservation in heteromorph ammonites from the Cenomanian-Turonian Boundary Event (OAE 2) in north-west Germany. Palaeontology, 55, 1307-1331. https://doi.org/ 10.1111/j.1475-4983.2012.01196.x

Klug C, Schweigert G, Tischlinger H, Pochmann H (2021) Failed prey or peculiar necrolysis? Isolated ammonite soft body from the Late Jurassic of Eichstätt (Germany) with complete digestive tract and male reproductive organs. Swiss Journal of Palaeontology

Kruta, I., Landman, N., Rouget, I., Cecca, F., \& Tafforeau, P. (2011). The role of ammonites in the mesozoic marine food web revealed by jaw preservation. Science, 331, 70-72. https://doi.org/10.1126/science.1198793

Kruta, I., Bardin, J., Smith, C. P. A., Tafforeau, P., \& Landman, N. (2020). Enigmatic hook-like structures in Cretaceous ammonites (Scaphitidae). Palaeontology, 63, 301-312

Landman, N. H., Mapes, R. H., \& Cruz, C. (2010). Jaws and soft tissues in ammonoids from the Lower Carboniferous (Upper Mississippian) Bear Gulch Beds, Montana, USA. In K. Tanabe, T. Sasaki, Y. Shigeta, \& H. Hirano (Eds.), Cephalopods - present and past. (pp. 147-153). Tokai University Press.

Landman, N. H., Polizzotto, K., Mapes, R. H., \& Tanabe, K. (2006). Cameral membranes in prolecanitid and goniatiitid ammonoids from the Permian Arcturus Formation, Nevada, USA. Lethaia, 39, 365-379

Lehmann, J., Hoffmann, R., Owen, H., \& Beckert, W. (2016). Cephalopoden aus unterkreidezeitlichen Geschieben der Region um Wolgast-Hohendorf, Vorpommern. Archiv für Geschiebekunde, 7, 401-530

Lehmann, U. (1981). Ammonite jaw apparatus and soft parts. In M. R. House \& J. R. Senior (Eds.), The ammonoidea. (Vol. 18, pp. 275-287). Systematic Association.

Lehmann, U. (1985). Zur anatomie der ammoniten: Tintenbeutel, kiemen, augen. PalZ, 59, 99-108. https://doi.org/10.1007/BF02986003

Lehmann, U., \& Weitschat, W. (1973). Zur Anatomie und Ökologie von Ammoniten: Funde von Kropf und Kiemen. Paläontologische Zeitschrift, 47(1), 69-76. https://doi.org/10.1007/BF02989563

Lemanis, R. (2020). The ammonite septum is not an adaptation to deep water: re-evaluating a centuries-old idea. Proceedings of the Royal Society $B$ : Biological Sciences, 287(1936), 20201919. https://doi.org/10.1098/rspb. 2020.1919

Lemanis, R., Korn, D., Zachow, S., Rybacki, E., \& Hoffmann, R. (2016). The evolution and development of cephalopod chambers and their shape. PLOS ONE, 11, e0151404. https://doi.org/10.1371/journal.pone.0151404

Lemanis, R., Zachow, S., Fusseis, F., \& Hoffmann, R. (2016b). A new approach using high-resolution computed tomography to test the buoyant properties of chambered cephalopod shells. Paleobiology, 41, 313-329. https://doi.org/10.1017/pab.2014.17

Lemanis, R., Zachow, S., \& Hoffmann, R. (2016c). Comparative cephalopod shell strength and the role of septum morphology on stress distribution. PeerJ, 4, e2434. https://doi.org/10.7717/peerj.2434

Lowenstam, H. A., Traub, W., \& Weiner, S. (1984). Nautilus hard parts: a study of the mineral and organic constitutions. Paleobiology, 10, 269-279

Maeda, H., \& Seilacher, A. (1996). Ammonoid taphonomy. In N. H. Landman, K. Tanabe, \& R. A. Davis (Eds.), Ammonoid paleobiology. (pp. 543-578), Boston, MA: Springer. https://doi.org/10.1007/978-1-4757-9153-2_14

Mähler, B., Janssen, K., Tahoun, M., Müller, C., Menneken, M., Bierbaum, G., Rust, J., \& Lagos, M. (2020). Calcite precipitation forms crystal clusters and muscle mineralization during the decomposition of Cambarellus diminutus (Decapoda: Cambaridae) in freshwater. Palaeontologia Electronica, 23, 3. https://doi.org/10.26879/992

Mapes, R. H., Landman, N. H., \& Klug, C. (2019). Caught in the act? Distraction sinking in ammonoid cephalopods. Swiss Journal of Palaeontology, 138, 141-149. https://doi.org/10.1007/s13358-018-0176-7
Mironenko, A. (2015). Soft-tissue preservation in the Middle Jurassic ammonite Cadoceras from Central Russia. Swiss Journal of Palaeontology, 134, 281-287. https://doi.org/10.1007/s13358-015-0082-1

Mironenko, A. (2017). Siphuncle soft-parts in the Upper Jurassic ammonite Kachpurites fulgens. Palaios, 32, 153-157

Obata, I., Tanabe, K., \& Fukuda, Y. (1980). The ammonite siphuncular wall: Its microstructure and functional significance. Bulletin of the National Science Museum. Tokyo Series C (Geology \& Palaeontology), 6, 59-72

Peterman, D., Ciampaglio, C., Shell, R., \& Yacobucci, M. (2019). Mode of life and hydrostatic stability of orthoconic ectocochleate cephalopods: Hydrodynamic analyses of restoring moments from 3D printed, neutrally buoyant models. Acta Palaeontologica Polonica, 64, 441-460. https://doi.org/10. 4202/app.00595.2019

Peterman, D. J., Barton, C., \& Yacobucci, M. (2019). The hydrostatics of Paleozoic ectocochleate cephalopods (Nautiloidea and Endoceratoidea) with implications for modes of life and early colonization of the pelagic zone. Palaeontologia Electronica. https://doi.org/10.26879/884

Peterman, D. J., Hebdon, N., Ciampaglio, C. N., Yacobucci, M. M., Landman, N. H., \& Linn, T. (2020). Syn vivo hydrostatic and hydrodynamic properties of scaphitid ammonoids from the U.S. Western Interior. Geobios, 60, 79-98. https://doi.org/10.1016/j.geobios.2020.04.004

Peterman, D. J., Mikami, T., \& Inoue, S. (2020). The balancing act of Nipponites mirabilis (Nostoceratidae, Ammonoidea): Managing hydrostatics throughout a complex ontogeny. PLOS ONE, 15(8), e0235180. https://doi.org/10. 1371/journal.pone.0235180

Peterman, D. J., Yacobucci, M. M., Larson, N. L., Ciampaglio, C., \& Linn, T. (2020). A method to the madness: Ontogenetic changes in the hydrostatic properties of Didymoceras (Nostoceratidae: Ammonoidea). Paleobiology. https://doi.org/10.1017/pab.2020.14

Polizzotto, K., Landman, N. H., \& Klug, C. (2015). Cameral membranes, pseudosutures, and other soft tissue imprints in ammonoid shells. In C. Klug, D. Korn, K. De Baets, I. Kruta, \& R. H. Mapes (Eds.), Ammonoid paleobiology: From anatomy to ecology. (pp. 91-109). Springer Netherlands. https://doi. org/10.1007/978-94-017-9630-9_4

Prévôt, L., \& Lucas, J. (1984). Apatite synthesis by bacterial activity from phosphatic organic matter and several calcium carbonates in natural freshwater and seawater. Chemical Geology, 42, 101-118

Saunders, W., Spinosa, C., Teichert, C., \& Banks, R. C. (1978). The jaw apparatus of Recent Nautilus and its palaeontological implications. Palaeontology, 21, 129-141

Tajika, A., Landman, N. H., Hoffmann, R., Lemanis, R., Morimoto, N., Ifrim, C., \& Klug, C. (2020). Chamber volume development, metabolic rates, and selective extinction in cephalopods. Scientific Reports, 10(1), 2950. https:// doi.org/10.1038/s41598-020-59748-z

Tanabe, K., Kruta, I., \& Landman, N. H. (2015). Ammonoid buccal mass and jaw apparatus. In C. Klug, D. Korn, K. De Baets, I. Kruta, \& R. H. Mapes (Eds.), Ammonoid paleobiology: From anatomy to ecology. (pp. 429-484). Springer Netherlands. https://doi.org/10.1007/978-94-017-9630-9_10

Tanabe, K., Kulicki, C., \& Landman, N. H. (2005). Precursory siphuncular membranes in the body chamber of Phyllopachyceras and comparisons with other ammonoids. Acta Palaeontologica Polonica, 50, 9-18

Tanabe, K., Fukuda, Y., \& Obata, I. (1982). Formation and function of the siphuncle-septal neck structures in two Mesozoic ammonites. Transaction Proceedings of Palaeontological Society of Japan, New Series, 128, 433-443

Tanabe, K., Mapes, R., \& Sasaki, T. (2000). Soft-part anatomy of the siphuncle in Permian prolecanitid ammonoids. Lethaia, 33, 83-91. https://doi.org/10. 1080/00241160050150212

Tanabe, K., Sasaki, T., \& Mapes, R. H. (2015). Soft-part anatomy of the siphuncle in ammonoids. In C. Klug, D. Korn, K. De Baets, I. Kruta, \& R. H. Mapes (Eds.), Ammonoid paleobiology: From anatomy to ecology. (pp. 531-544). Springer Netherlands. https://doi.org/10.1007/978-94-017-9630-9_13

Tucker ME (1985) Einführung in die Sedimentpetrologie- 265 S., 219 Abb., 20 Tab. Stuttgart (Ferdinand Enke)

Weitschat W (1986) Phosphatisierte Ammonoideen aus der Mittleren Trias von Central-Spitzbergen. Mitteilungen aus dem Geologisch-Paläontologischen Institute der Universität Hamburg 61:249-279

Weitschat, W., \& Bändel, K. (1991). Organic components in phragmocones of boreal triassic ammonoids: Implications for ammonoid biology. Paläontologische Zeitschrift, 65, 269-303. https://doi.org/10.1007/BF02989845 
Wilby, P., Hudson, J., Clements, R., \& Hollingworth, N. (2004). Taphonomy and origin of an accumulate of soft-bodied cephalopods in the Oxford Clay Formation (Jurassic, England). Palaeontology, 47, 1159-1180. https://doi. org/10.1111/j.0031-0239.2004.00405.x

Wippich, M. G. E., \& Lehmann, J. (2004). Allocrioceras from the Cenomanian (mid-Cretaceous) of the Lebanon and its bearing on the palaeobiological interpretation of heteromorphic ammonites. Palaeontology, 47, 1093-1107. https://doi.org/10.1111/j.0031-0239.2004.00408.x

\section{Publisher's Note}

Springer Nature remains neutral with regard to jurisdictional claims in published maps and institutional affiliations. 